\title{
Eneas Silvio Piccolomini (Pío II) y su concepción de Europa
}

\section{Aeneas Silvius Piccolomini (Pius II) and his conception of Europe}

\author{
Arsenio GinZo FERNÁNDEZ \\ Universidad de Alcalá de Henares \\ arsenio.ginzo@uah.es
}

Recibido: 21-10-2009

Aceptado: 28-01-2010

\section{Resumen}

El Papa y humanista Eneas Silvio Piccolomini (Pío II) es aquel autor medieval que más explícita e insistentemente se ha ocupado del problema de Europa, no sólo como entidad geográfica sino también política, religiosa y cultural. El artículo analiza los rasgos fundamentales de su concepción de Europa, en el horizonte de los grandes problemas de su tiempo. Por una parte la amenaza turca sobre Europa y por otra las transformaciones internas de Europa, tanto políticas como religiosas.

Palabras clave: Pensamiento medieval, humanismo cristiano, Europa, Occidente y Oriente, Islam.

\begin{abstract}
The humanist and Pope Aeneas Silvius Piccolomini (Pius II) is the medieval thinker who most openly and constantly deals with the problem of Europe, not only as a geographical, but also as a political, religious and cultural reality. This article tries to show the main characteristics of his conception of Europe, in the framework of the great problems of his time : on the one hand the turkish threat over Europe and on the other hand Europe's inner changes, both political and religious.
\end{abstract}


Keywords: Medieval thought, Christian humanism, Europe, West and East, Islam.

\section{Europa y la Edad Media}

Sin duda a lo largo del pensamiento moderno, podemos perseguir toda una serie de pronunciamientos, de meditaciones acerca de la identidad europea, acerca las características que a juicio de cada pensador definiría el ser europeo en el marco de la Historia universal. Se trata, en efecto, de una línea de reflexión que es fácil de perseguir desde los humanistas renacentistas, como Erasmo y Vives, hasta pensadores tan representativos del siglo XX como Husserl, Ortega y Gasset, Heidegger, Derrida..., pasando desde luego a través de autores como Leibniz, los ilustrados, los representantes del Idealismo alemán y Nietzsche, entre otros varios.

Dentro de ese horizonte nuestro propósito en estas páginas consiste en aproximarnos a la concepción de Europa que nos ofrece aquel autor medieval que más explícita e insistentemente se ha ocupado del problema europeo como tal. Se trata del humanista del siglo XV Eneas Silvio Piccolomini, el futuro Papa Pío II (14051464). Tanto como humanista como en su condición de Papa el problema de Europa se encuentra en el centro de su pensamiento y de su actividad en general. Entre otras cosas es el autor de un tratado medieval que incluye ya en el título la palabra "Europa"1. Este hecho no constituye un mero detalle anecdótico sino que estamos en realidad ante aquel autor medieval que con más frecuencia y apasionamiento aborda en su obra el problema de Europa como entidad no sólo geográfica sino a la vez religiosa, política y cultural. Asimismo Eneas Silvio Piccolomini es aquel autor que acierta a denominar como "europeos" a los habitantes del Continente2 ${ }^{2}$ Cabría recordar a este respecto cómo todavía Dante al hacer referencia a "la mayoría de los europeos" utiliza el circunloquio "maior pars Europam colentium"3, por carecer de un término específico para designarlos.

Con ello Eneas Silvio se iba a convertir a juicio de muchos intérpretes en uno de los grandes europeístas que van a jalonar la historia del pensamiento europeo a partir del humanismo renacentista. Cabría decir que nuestro autor anticipa las Meditationes de Europa tan frecuentes en la Modernidad y que por el contrario tan escuetas y raras van a ser a lo largo de la Edad Media.

\footnotetext{
1 Eneas Silvio Piccolomini, La Europa de mi tiempo (1405-1458), Sevilla, Universidad de Sevilla, Secretariado de Publicaciones, 1998.

2 Aeneae Silvii Piccolominei Senensis, qui post adeptum Pontificatum Pius eius nominis secundus appellatus est, Opera quae extant omnia, Basilea, per Henrichum Petri, 1551, 387. (En adelante : Opera omnia).

3 Dante Aliegheri, Monarchia III, 14.
} 
En algún sentido esto último resulta tanto más paradójico cuanto que fue precisamente durante la Edad Media cuando se formó y se articuló la idea de Europa como algo más que una referencia geográfica. Inspirada en los dos grandes legados que subyacen a la cultura europea, el grecorromano y el judeocristiano, e integrando las nuevas realidades que aportaban los pueblos germánicos, Europa, cabría decir, se nos presenta como una gran creación de la Edad Media. Por muchas cuestiones que puedan permanecer abiertas, y sobre las que se pueda seguir discutiendo, cabría suscribir la afirmación de Jacques Le Goff según la que "la Edad Media es la época en que apareció y se gestó Europa como realidad y como representación y que constituyó el momento decisivo del nacimiento, infancia y juventud de Europa"4. Y asimismo cabría suscribir las palabras de Leo Moulin cuando señala que sin recurrir a la Edad Media "resulta imposible explicar el destino, tan particular de Europa, sin la acción de sus grandes siglos luminosos", de forma que sin ellos "Europa no sería lo que es" 5. Cabría, en definitiva, concluir con Ortega que la Edad Media constituye uno de los momentos estelares de la afirmación de Europa. En efecto, cuando en su ensayo De Europa meditatio quaedam quiere destacar dos momentos singulares de la afirmación de Europa a lo largo de la historia, Ortega señala por un lado la aurora de la historia europea, el siglo de Carlomagno, y por otro el siglo XVIII, el siglo de la Ilustración 6 , aquel siglo en el que Rousseau no veía "más que europeos", y no ya franceses, alemanes, españoles o ingleses7. Teniendo todo esto presente, trataremos de situar nuestra aproximación al pensamiento de Eneas Silvio Piccolomini en estrecha vinculación con las coordenadas generales de la concepción medieval de Europa.

Tal como recuerda Ortega, el nacimiento de Europa como realidad política, religiosa y cultural va unida a la figura de Carlomagno, cuyos territorios coincidían a grandes líneas con los de los miembros fundadores de la Unión Europea, a mediados del siglo XX, y que giraban en torno a la Cristiandad latina. La época no va a dudar a la hora de vincular explícitamente a Europa y Carlomagno. Así lo hace de un modo especial el poeta Angilbert que se refiere a Carlomagno como al "Rex, pater Europae" o bien como al "Europae venerandus apex". Por su parte los Anales de Fulda hablan de "Europa vel regnum Caroli"8.

Sin duda, el periodo carolingio constituyó un brillante inicio en la formulación y articulación de la idea de Europa. Pero es bien sabido que ese proyecto pronto se

\footnotetext{
4 Jacques Le Goff, ¿Nació Europa en la Edad Media?, Barcelona, Crítica, 2003, 1.

5 Leo Moulin, "L'Europe, fille aînée du Moyen Age", en Philosophie Politique I (1991), 16.

6 J. Ortega y Gasset, "De Europa meditatio quaedam", en Obras completas IX, Madrid, Alianza, 1983, 261.

7 J.-J. Rousseau, Proyecto de Constitución para Córcega. Consideraciones sobre el Gobierno de Polonia y su proyecto de reforma, Madrid, Tecnos, 1988, 61.

8 Cfr. D. de Rougemont, Tres milenios de historia, Madrid, Revista de Occidente, 1963, 57, 58.
} 
va a deteriorar y a desintegrar y con ello se va a oscurecer la idea de Europa. Con ciertas matizaciones, cabría suscribir la afirmación de Denis de Rougemont en el sentido de que entonces habría comenzado el eclipse de la "conciencia" europea, aunque no así el de la "realidad" europea9. En efecto, el siglo XI, pero sobre todo el XII y el XIII han sido siglos de poderosa afirmación de la realidad europea, aun cuando la conciencia de la misma sea más bien débil y dispersa ${ }^{10}$.

En esa afirmación de la "realidad" europea cabría destacar cómo Europa vive una unidad profunda sin por ello anular la diversidad sin más. La Edad Media supo hacer suyo el ideal que más tarde formulará Leibniz :"Utique delectat nos varietas, sed reducta in unitatem". En efecto, a pesar de todas las diferencias y conflictos que caracterizaron a la Europa medieval, de orden político, religioso, administrativo, cabe hablar a la vez de su profunda unidad, como quizá nunca haya vuelto a tener. Es un rasgo que un romántico como Novalis no podrá menos de añorar, ante el espectáculo que ofrece el mundo moderno11. Y si bien la visión novalisiana nos ofrece una imagen idealizada de la Edad Media, la profunda unidad de la Europa medieval es algo incontestable. Lo es en primer lugar por lo que atañe a las creencias religiosas compartidas por la enorme mayoría de la población, a pesar de las diferencias que también en este plano pueden surgir; lo es por el mismo idioma culto vehículo de comunicación por doquier, el latín; por las nacientes Universidades, a partir del siglo XIII, que enseñan las mismas materias y utilizan los mismos métodos pedagógicos, aun cuando unas puedan destacar más en unas disciplinas que en otras; por las Órdenes religiosas que van tejiendo a lo largo de Europa toda una red de centros, situándose por encima de las divisiones territoriales; asimismo por la red de catedrales que se extienden por los distintos reinos, y en las que el arte y la religiosidad se funden para dar expresión a las mismas creencias; finalmente habría que referirse a los dos poderes universalistas actuantes en la Edad Media, el Imperio y el Papado. A pesar de sus conflictos y disputas, no cabe duda de que contribuyen a articular la unidad de la época, sobre todo antes de que el periodo final de la Edad Media suponga su claro declive.

He aquí algunos de los poderosos vínculos que configuran el tejido de la Europa medieval, en su periodo de plenitud. Y, sin embargo, para que renazca la toma de conciencia europea, hay que esperar a los siglos finales, al XIV y sobre todo al $X{ }^{12}$. Y dentro del siglo XV quien va tomar una conciencia más nítida del problema va a ser Eneas Silvio Piccolomini. A esta toma de conciencia va a contribuir de

\footnotetext{
9 Ibid., 6

10 Con diferencia de matices, suele haber acuerdo acerca de este punto entre los diversos estudiosos sobre la idea de Europa en la Edad Media.

11 Novalis, Werke, C.H.Beck, München, 1969, 499 ss.

12 Véase, por ejemplo, D. Hay, Europe. TheEmergence of an Idea, Edinburgh, Edinburgh University Press, 1968.
} 
una forma poderosa el hecho de que Europa se viera entonces seriamente amenazada por un enemigo externo, los turcos, que traían consigo un modelo religioso y cultural ajeno a la tradición europea. Al tomar conciencia de esta situación, algunos de los espíritus más destacados de la época no dudan en señalar que este conflicto entre dos modelos religiosos, culturales y políticos no es más que un nuevo capítulo de la confrontación entre el espíritu "europeo" y el "asiático" que habría iniciado la Grecia clásica en su oposición a los persas. Por ello nos parece pertinente evocar brevemente la historia de esta cuestión, pues Eneas Silvio Piccolomini y los humanistas coetáneos no dudaron en referirse a esta vieja confrontación cuando trataban de comprender la situación histórica que les había correspondido vivir, en la que Europa se enfrentaba a la amenaza turca.

\section{La conciencia de Europa y las amenazas externas}

Uno de los mejores historiadores de la idea de Europa, Federico Chabod, señala que "El concepto de Europa debe formarse por contraposición en cuanto existe algo que no es Europa; comparándose con lo que no es Europa es precisamente, al menos al principio, como adquiere sus características y se acusa en sus elementos"13. En este sentido, la primera contraposición entre el espíritu europeo y algo que no es Europa, y que va a servir de referencia durante muchos siglos, es un producto del pensamiento griego que a través de varios autores va a postular la oposición entre el espíritu griego, fundamento del espíritu europeo, y el asiático, que vendría a equivaler a su juicio a la oposición entre el espíritu de libertad y el despotismo. Ciertamente, Grecia, desde el punto de vista geográfico, no constituía más que una pequeña parte de Europa ${ }^{14}$. Pero espiritualmente constituye el fundamento del espíritu europeo, aquel ámbito en el que los europeos, tal como señalará Hegel, se encontrarán por primera vez como "en casa" 15.

Toda una serie de señalados autores griegos va a contribuir a formular esta contraposición entre griegos y asiáticos, que va a formar parte del legado griego a la tradición occidental, y por muy imprecisa que resulte la conciencia de Europa todavía. He aquí algún testimonio. Esquilo en Los Persas aborda el tema de la confrontación entre el espíritu griego y el asiático, personificado en los persas, al describir cómo un vigoroso halcón se precipita desde el cielo y se abalanza sobre la cabeza de un águila que se encoge impotente: "Y entonces veo un águila huyendo hasta el hogar que hay en el altar de Febo, y de miedo me quedo, amigos, sin voz.

13 F. Chabod, Historia de la idea de Europa, Norte y Sur, Madrid 1967, 31.

14 "Parvum quendam locum Europae tenet", escribe Cicerón en Pro Flacco, XXVII.

15 G.W.F. Hegel, Vorlesungen über die Geschichte der Philosophie I, Frankfurt a. Main, Suhrkamp, 1971, 173. 
Me fijo después en un halcón que, en veloz aleteo, se arroja sobre ella y con sus uñas le va arrancando plumas de la cabeza. Pero el águila no hacía otra cosa que hacerse un ovillo y abandonarse"16. El halcón simboliza a los griegos que se alzan victoriosos sobre los persas. Por su parte Isócrates señala en el Elogio de Helena :'Descubriremos, en efecto, que los griegos se pusieron de acuerdo por su causa e hicieron una expedición común contra los bárbaros y que entonces, por vez primera, Europa levantó un trofeo en Asia"17. También aquí el espíritu griego se alza victorioso sobre el asiático. El espíritu de libertad y de civilización se impone victorioso sobre la barbarie. Por su parte Aristóteles también se suma a esta defensa de la superioridad del espíritu griego. Así ocurre en un conocido pasaje de la Política en el que los griegos aparecen como superiores a los "europeos" y a los asiáticos. Los "europeos" se caracterizarían según Aristóteles por su coraje más bien que por su inteligencia mientras que con los asiáticos ocurriría al revés, les faltaría coraje y por ello no lograrían salir de su sujeción y esclavitud. Los griegos por el contrario serían a la vez valientes e inteligentes. De esta forma permanecerían libres y conservarían el mejor de los gobiernos, e incluso podrían someter a las demás naciones si se reunieran en un solo Estado18. Sin duda, "Europa" y "europeos" resultan todavía términos bastante imprecisos, pero lo relevante para nuestro propósito es la valoración que se ofrece de los griegos, de la superioridad de la libertad sobre la servidumbre y el despotismo, una superioridad que implicaría una mayor capacidad de autogobierno y asimismo de gobierno e influjo sobre los demás pueblos.

Tal contraposición entre el espíritu "europeo" y el "asiático" es, como queda apuntado, parte del legado que los griegos transmiten a la posteridad occidental, por muchas que sean las metamorfosis a que se vea sometido a lo largo de los tiempos. Así ocurrió con los romanos, discípulos de los griegos en tantas cuestiones. Grecia, una vez conquistada, conquistó a su feroz conquistador, escribirá gráficamente Horacio. Por lo que atañe a nuestro problema vemos que también en Roma se reproduce el conflicto con el mundo oriental y de nuevo surge una valoración del mismo afín al que habían proporcionado los griegos. Tal conflicto aparece protagonizado, por ejemplo, por Antonio y Cleopatra por un lado y Augusto por otro. Y de nuevo se estima que el espíritu superior de Occidente triunfaría sobre la esclavitud y servidumbre orientales 19 .

En esta estela va a proseguir el Cristianismo, con su apoyatura en el legado grecorromano. Así podemos ver cómo Gregorio Magno no duda en distinguir a los reyes bárbaros de los emperadores romanos en términos que hacen referencia al dis-

\footnotetext{
16 Esquilo, "Los persas", 200-210, en Tragedias, Madrid, Gredos, 1983, 226.

17 Isócrates, "Elogio de Helena”, en Discursos, Madrid, Gredos, 1979, 182-83.

18 Aristóteles, Política, cap. VII.

19 Cfr. Y. Gómez Sánchez y otros (eds), Enseñar la idea de Europa, Madrid, Centro de Estudios Ramón Areces y UNED, 2004, 29.
} 
frute de la libertad, de un modo que nos recuerda a los autores griegos ${ }^{20}$. Los bárbaros y los paganos constituyen ahora el referente frente al cual se va a afirmar la conciencia "europea".

Más adelante van a ser los musulmanes quienes constituyan el referente principal frente al que se reafirme la conciencia de la identidad europea. En primer lugar en cuanto el Islam se apodera de amplias zonas de Asia y África que previamente formaban parte de la Cristiandad, incluida, obviamente, Tierra Santa. Con ello el Cristianismo se veía recluido cada vez más en el ámbito europeo y se consolidaba como una de sus señas de identidad. Pero, por otra parte, se van a producir diferentes incursiones islámicas en el propio territorio europeo, constituyendo uno de los hitos la batalla de Poitiers en 732, mediante la cual se detiene su avance sobre Europa. No deja de ser significativo que el autor anónimo de la Crónica que describe esta batalla se refiera a los soldados procedentes de distintas regiones, y que ganan la batalla contra los árabes, como "Europenses". He aquí la afloración de un término que va a servir para designar a una comunidad de pueblos que se bate contra un enemigo común 21.

Sin duda, a lo largo del pensamiento medieval cabe perseguir toda una línea que propiciaba el diálogo entre el Cristianismo y el Islam ${ }^{22}$. No es éste el lugar de detenernos sobre ello. Baste con recordar que, entre otros muchos, participaron en ese diálogo antores tan ilustres como Raimundo Lulio, Juan de Segovia o Nicolás de Cusa. Sin embargo, la actitud predominante en la Europa cristiana era la de un oposición clara a la nueva amenaza que provenía del exterior, lo cual conducía a una actitud tan típicamente medieval como es el espíritu de cruzada contra el infiel. Así lo podemos constatar, por ejemplo, en los sermones de Urbano II en pro de la Cruzada en 1095. Frente a la amenaza exterior, emerge en los sermones papales una conciencia de la identidad europea que implica sus aspectos religiosos, políticos y culturales ${ }^{23}$. Al mismo tiempo, no deja de ser significativo que los sermones del Papa hagan suyos los tópicos puestos en circulación por los griegos en torno a los europeos y los asiáticos. Resulta por lo demás bien comprensible que en este horizonte se haya desarrollado en el seno de la tradición cristiana toda una literatura que polemizaba con el Islam. Tal es el caso, entre otros, de Pedro el Venerable, con su tratado Summa totius haeresis Saracenorum, del propio Santo Tomás con su Summa contra Gentiles o bien su De rationibus fidei, o el del coetáneo de Eneas Silvio Piccolomini, Juan de Torquemada, con su escrito Tractatus contra principales errores perfidi Machometi, de título suficientemente significativo.

20 Cfr. D. Hay, op. cit., 23.

21 D. de Rougemont, op. cit., 56.

22 Véase, por ejemplo, N. Daniel, Islam and the West: the Making of an Image, One World, Oxford, 2009.

23 B. Karageorgos, "Der Begriff Europa im Hoch- und Spätmittelalter", en Deutsches Archiv für Erforschung des Mittelalters, XLVIII (1992), 139-40. 
Eneas Silvio Piccolomini y su época se vieron confrontados de una forma más específica con la amenaza turca que culminó no sólo con la conquista de Constantinopla sino que se agravó con el ulterior avance sobre Europa. La meditación sobre Europa del Papa humanista resulta inseparable de esta circunstancia. Cabría afirmar a este respecto que la concepción de Europa en la tarda Edad Media $\mathrm{y}$ en los primeros siglos de la Modernidad tiene entre sus motivos fundamentales el contraste entre la cultura europea y la que encarnaban los turcos como amenaza externa 24 . Tal amenaza obligaba a plantearse los rasgos de la propia identidad, con un apremio especial, tal como va a ser el caso de Eneas Silvio Piccolomini y de la corriente humanista en general.

Este referente turco que incidía tanto en la praxis como en la toma de conciencia de los europeos es algo que está presente en el horizonte europeo desde mediados del siglo XIV hasta muy entrada la Edad Moderna. Para nuestro propósito en estas páginas es suficiente con recordar algunos datos de la primera fase de esta penetración turca que contribuyó a desestabilizar considerablemente al Oriente europeo, que ya de por sí se encontraba en una situación bastante precaria. Esta penetración comenzaba a mediados del siglo XIV, con la toma de Gallipoli y Tracia del sur entre los años 1353 y 1356. A partir de ahí se van a suceder otras varias derrotas a manos de las tropas otomanas. Así Salónica cae en 1387 y dos años más tarde los serbios van a sufrir una severa derrota en Kosovo. En esta situación el emperador Segismundo va a organizar una cruzada contra los turcos, pero los convocados van a ser claramente derrotados el año 1396 en Nicópolis ${ }^{25}$. Esta penetración otomana en suelo europeo va a proseguir a lo largo del siglo XV, alcanzando su clímax con la toma de Constantinopla, de enorme valor simbólico, y que causó un gran impacto en la conciencia europea. Por otra parte el avance otomano no se iba a detener ahí sino que cobra nuevos bríos para seguir avanzando sobre Europa, cabiendo destacar aquí la toma de Bosnia en los años 1463-66.

Una agresión de tal envergadura no podía menos de conmocionar profundamente a Europa, al menos en los ambientes eclesiásticos y humanistas. Por supuesto también en los ambientes políticos más directamente afectados. En todo ello un hecho se imponía sobre los demás : la caída de Constantinopla en manos turcas. Por ello nos vamos a detener un momento sobre este acontecimiento, aunque más adelante tendremos que volver de nuevo sobre él.

${ }^{24}$ F-.R. Erkens, Europa und die osmanische Expansion im ausgehenden Mittelalter, Berlín, Duncker \& Humblot, 1997, 7 - 8.

25 J. Le Goff, op. cit., 163. 


\section{La caída de Constantinopla y el problema de Europa}

La toma de Constantinopla por los turcos el 29 de mayo de 1453 constituyó un acontecimiento epocal en la historia de Europa, una de sus fechas referenciales, una línea divisoria entre la Edad Media y la Moderna. Se trataba, en efecto, de la caída de la segunda Roma ${ }^{26}$, de la capital del Imperio Romano de Oriente, con toda su secuela de consecuencias políticas, religiosas y culturales. La confrontación entre el espíritu asiático y el europeo alcanzaba ahora un punto especialmente álgido, en una coyuntura en que las tropas provenientes de Asia se imponían sobre Europa, a la que acababan de arrebatar una de sus referencias simbólicas.

Sin duda, a pesar de las conquistas turcas llevadas a cabo en el Continente europeo, Constantinopla seguía constituyendo un baluarte frente a la amenaza turca, que protegía al resto del Continente. De esta forma, su caída dejó a Europa, sobre todo a sus territorios más orientales, más desguarnecidos y vulnerables. Se comprende que ya desde esta perspectiva, su caída haya resultado traumática para la conciencia europea. Pero aparte de su valor estratégico, estaba su profunda relevancia simbólica desde el punto de vista político, religioso y cultural. Tal como queda apuntado, se trataba de la segunda Roma, de la capital del Imperio Romano de Oriente, que había recibido su nombre del emperador Constantino. No sorprende, por tanto, que a la hora de buscar un paralelismo de esta catástrofe en el pasado, varios autores de la época, entre ellos el propio Eneas Silvio Piccolomini, vieran en ella un caso equiparable al saqueo de Roma en 410 por las tropas de Alarico.

Tal como se ha podido señalar, más allá de los daños materiales, nos encontramos en ambos casos ante el derrumbamiento de un "mito", de la afrenta ocasionada a lugares considerados como sagrados e inviolables ${ }^{27}$. En el caso de Roma, la capital política del mundo antiguo, la renombrada Ciudad Eterna, encumbrada por tantos autores, entre ellos por Virgilio, Horacio o Tito Livio, tal carácter intocable y "sagrado" resultaba bien plausible. Pero hasta cierto punto también lo parecía el status de Constantinopla. Desde el horizonte político, estaba su condición de capital del Imperio Romano de Oriente, por mucho que hubiera decaído de su antiguo esplendor; desde el punto de vista eclesiástico, en cuanto era uno de los centros más emblemáticos de la Cristiandad, que encontraba en una maravilla como Santa Sofía su expresión idónea; finalmente desde el punto de vista cultural en cuanto era portadora del legado de la Grecia clásica, de su idioma y de sus grandes creaciones literarias, filosóficas, historiográficas y científicas, algo particularmente relevante para un Occidente latino en un momento en que, empujado por los vientos del naciente humanismo renacentista, volvía a estudiar griego y a buscar inspiración en los textos originarios de la cultura europea.

26 O bien la Nueva Roma, tal como la había designado el Concilio de Constantinopla de 381.

27 L. Rotondi Secchi Tarugo (ed.), Pío II e la cultura del suo tempo, Milano, Istituto di Studii Umanistici F. Petrarca Mentis Itinerarium, 1991, 263. 
Es bien comprensible por ello que la caída de la gran ciudad, con su profundo significado político, religioso y cultural, haya resultado traumática no sólo para Bizancio y territorios limítrofes sino también para los círculos eclesiásticos y humanistas del Occidente latino. Un acontecimiento de esta envergadura, por otra parte, no podía menos de fomentar el sentimiento apocalíptico, de final de los tiempos, que con frecuencia emergía en la conciencia medieval, tal como fue, por ejemplo, el caso con motivo de la peste negra. Ahora la caída de una ciudad tan cargada de simbolismo no podía menos de reavivar considerablemente tal estado de ánimo. En este sentido podemos ver cómo el propio Nicolás $\mathrm{V}$, bajo cuyo pontificado tuvo lugar la caída de la ciudad, identifica al conquistador de la misma, el sultán Mehmet II, con el "gran dragón de fuego" de que habla el Apocalipsis (Ap. 12, 3)28. Tal sentimiento resultaba más vivo todavía en la medida en resultaba patente que los planes turcos de avanzar sobre Europa iban a proseguir su curso. Nadie va a tener una conciencia tan viva de este problema y de las implicaciones que se podían derivar como Eneas Silvio Piccolomini.

\section{Latinos y bizantinos}

Ciertamente la conciencia europea, desde los griegos, es inseparable de su confrontación con Oriente, con el espíritu asiático, que para nuestros efectos comenzaron personificando los persas. Por mucho que pueda haber de tópico, no suficientemente analizado, en tal planteamiento, resulta innegable que esa confrontación ayudó a Europa a tomar una conciencia más clara de sí misma. Desde los persas hasta los turcos, a finales de la Edad Media, tal parece haber sido el caso. No parece necesario insistir aquí ulteriormente sobre este punto. Por el contrario consideramos pertinente evocar la tensión entre Occidente y Oriente existente en el interior de la propia Europa, la tensión entre Latinos y Bizantinos.

Se trata, en efecto, de una tensión muy relevante por lo que a la toma de conciencia de Europa se refiere. En realidad, tanto Latinos como Bizantinos no sólo pertenecen geográficamente al Continente europeo sino que remiten y se apoyan en el doble legado que subyace a Europa : el judeocristiano y el grecorromano, aun cuando lo hagan de una forma distinta. Sin embargo, a pesar de los elementos comunes que unían al Occidente y al Oriente europeos, varios van a ser también los desencuentros que se van a ir configurando a lo largo del tiempo entre ambas partes hasta que llegaron a convertirse en una especie de "hermanos enemigos", tal como escribe gráficamente Basileos Karageorgos 29 .

28 B. Guthmüller und W. Kühlmann (eds), Europa und die Türken in der Renaissance, Tübingen, Max Niemeyer, 2000, 36.

29 B. Karageorgos, op. cit., 161. 
Tanto desde el punto de vista lingüístico como político y religioso se fue produciendo un extrañamiento entre Latinos y Bizantinos, acompañado de múltiples tensiones. En la historia de los desencuentros entre ambas partes cabría destacar al menos dos fechas : desde el punto de vista religioso el año 1054 que consagra el llamado Cisma de Oriente, con su negativa a aceptar el primado del Papa, y desde el punto de vista político el año 1204 en el que con motivo de la cuarta cruzada los cruzados conquistaron y saquearon Constantinopla, agravando las tensiones y reticencias existentes entre ambas partes. Con anterioridad a ambas fechas, está el hecho de la emergencia de Europa como entidad política con Carlomagno en cuanto identificada con la Cristiandad latina, de forma que Bizancio no parecía pertenecer a una Europa así concebida. Cabría por ello afirmar que el nacimiento de la Europa carolingia también contribuyó a ahondar en la separación entre latinos y griegos. Tal como señala W. Ullmann :"Se consideraba el continente dividido entre unos territorios latinos y otros griegos, de los que tan sólo los primeros eran Europa"30. Aunque desde perspectivas distintas, tanto Latinos como Bizantinos compartían este punto de vista. Sin duda los Bizantinos continuaban en el plano político considerando que su Imperio era el único legítimo mientras que en plano religioso consideraban que su interpretación de la doctrina cristiana era la correcta, la "ortodoxa". Pero por lo que se refería a "Europa" ellos la identificaban con la Cristiandad latina. Así vemos que cuando un autor como Gennadios Scholarios se refiere a autores Latinos los llama "Europaioi".

No obstante, a pesar de esta visión restrictiva de "Europa", a pesar asimismo de tantos desencuentros y fricciones entre ambas partes, tenía que abrirse paso a la vez la conciencia de toda una serie de elementos comunes, de orden religioso, cultural y político y geográfico, lo cual habría de conducir a una visión más amplia e integradora de Europa. Sin duda el grado de identificación con Europa se mostraba distinto en cada caso. Quizá cabría hablar en este sentido con Rémi Brague de que Europa es un concepto variable, de que se es más o menos europeo, de forma que se podría afirmar que el mundo griego y ortodoxo pertenece menos unívocamente a Europa que la Cristiandad latina ${ }^{31}$. Hasta cierto punto se trataba en este último caso de lo que Hegel denominará más tarde el "corazón" de Europa en oposición a la Europa oriental. No obstante, tal conciencia de superioridad ya es común a los latinos medievales. El mundo bizantino habría ido decayendo, en los distintos frentes, de su antiguo esplendor. Además, los desencuentros religiosos y políticos contribuían por su parte a una visión peyorativa por parte de los Latinos.

Van a ser la presencia y la amenaza del enemigo exterior, aquel que cuestionaba los fundamentos comunes, las que den cohesión al conjunto de Europa. Así lo podemos constatar en los mencionados sermones de Urbano II convocando la cru-

30 W. Ullmann, Historia del pensamiento político en la Edad Media, Barcelona, Ariel, 1983, 68-69.

31 R. Brague, Europa. Eine excentrische Identität, Campus, Frankfurt a. M - New York, 1993, 20. 
zada. Frente al enemigo común, Europa se le presenta como una unidad que abarca también la parte oriental. Hasta cierto punto esto también va a ocurrir más tarde, cuando sean los turcos quienes acosan a Europa oriental. Sin duda la incursión turca va a servir para reafirmar la conciencia europea, y también la de su unidad de fondo, a pesar de la persistencia de sus conflictos y discrepancias. Tal va a ser en concreto el horizonte en que se va a mover Eneas Silvio Piccolomini que tan en serio se tomó no sólo el problema de Europa en general, sino más específicamente el de la Europa oriental, víctima del enemigo externo, ajeno a la tradición europea32.

Por su parte los Bizantinos fueron también conscientes de los elementos comunes que les unían con los Latinos y por ello, al ser víctimas de la agresión turca, no dudan en dirigirse a los Latinos en busca de ayuda frente al enemigo exterior. Ello ocurría mucho antes de la caída de Constantinopla. Ya desde 1320 los Bizantinos se dirigieron a los Latinos solicitando esa ayuda. Sin embargo, las discrepancias religiosas, primero, y después también las divisiones políticas del Occidente latino van a impedir que ambas partes de Europa llegaran a colaborar debidamente en la defensa contra el adversario común.

Desde el punto de vista religioso, la petición de ayuda a los Latinos tropezó con el obstáculo de que se les exigía a los Bizantinos la sumisión a Roma como condición para que se hiciera efectiva tal ayuda. La inacción de los Latinos y el aumento de la presión turca hacen que los griegos terminen sometiéndose en el Concilio de Ferrara-Florencia celebrado en 1438-39. En Occidente se organiza entonces una cruzada contra los turcos pero va a terminar con la desastrosa derrota de Varna en 1444. La toma de Constantinopla estaba ya próxima y los Bizantinos se vieron prácticamente abocados a su suerte. Tal como señala James Hankins, cabe hablar de una cierta ambigüedad por parte de los occidentales ante el destino de los Bizantinos. Por un lado se recurría al pretexto de que ellos merecían el castigo recibido de manos de los turcos, debido a su actitud religiosa y política. Pero por otro lado no pueden evitar un sentimiento de mala conciencia por no haber ayudado más decididamente a aquellos griegos con los que, a pesar de todo, seguían teniendo tantos elementos comunes, en su lucha con un enemigo que también les era común ${ }^{33}$. Cuando en 1458 Eneas Silvio Piccolomini es elegido Papa, va a esforzarse por aglutinar a los gobernantes occidentales en una especie de cruzada contra el Turco. Pero entonces, según veremos, va a quedar patente la desunión y el desinterés de la Europa política para hacer frente al peligro, de forma que esa Europa política, en un momento de emergencia de las nacionalidades, vive más pendiente de sus intereses particulares que de la defensa común del Continente. A pesar de todo la toma de conciencia europea, de su identidad y de sus problemas, va a encontrar un decidido

32 Véase, por ejemplo, F. Guida, "Enea Silvio Piccolomini e L'Europa orientale : il "De Europa" (1458)", en Clío 15(1979), 35-77.

33 J. Hankins, op. cit., 133. 
valedor en la figura de Eneas Silvio Piccolomini (Pío II), en los medios eclesiásticos, y también en la corriente humanista, para la que la oposición al Turco no se limitaba a ser un problema político y religioso sino que se convertía en la defensa de un modelo de civilización que se veía cuestionado por la amenaza exterior. Vamos a evocar brevemente esta corriente humanista, pues resulta relevante para la mejor comprensión del horizonte en que se mueve Eneas Silvio Piccolomini, en la medida en que éste se hace portavoz, en su lucha contra el Turco, no sólo de la dimensión religiosa sino también cultural, pues nos hallamos ante la figura de un Papa humanista.

\section{El movimiento humanista y los turcos}

La penetración turca en Europa, sus sucesivas victorias, y de una forma especial la conquista de Constantinopla y el posterior avance sobre el Continente europeo, no iba a tener sólo implicaciones políticas y religiosas, tal como se ha apuntado. El movimiento humanista y su oposición a la invasión turca en nombre de la defensa de un modelo de civilización va a constituir un elemento destacado de esta oposición de la Europa tardomedieval al enemigo exterior. Los humanistas van a hacer suya la vieja idea medieval de la cruzada, pero no cabe duda de que le van a hacer experimentar una inflexión, en la medida en que el problema de la cruzada se sitúa en el horizonte de una lucha entre la civilización y la barbarie, aun cuando, por supuesto, se incluyan también otros aspectos de la idea de cruzada como era el religioso. De ahí el fenómeno frecuente de pretender aunar ambos elementos en la oposición al Turco en el seno del humanismo cristiano que cabe perseguir fácilmente desde Petrarca hasta las grandes figuras del humanismo renacentista como Vives, Erasmo, Moro y Budé. Estamos ante el fenómeno de la "litterata devotio", de la "docta pietas", que desde Petrarca se ha caracterizado por buscar la convergencia entre la sabiduría clásica y la tradición cristiana. A este proyecto se van a sumar, entre otros, tanto nuestro autor, sobre el que volveremos más adelante, como su predecesor como Papa Nicolás V. Este Papa, que no había dudado en referirse al sultán conquistador de Constantinopla como el gran dragón rojo del Apocalipsis, se mostraba como un gran mecenas de sabios y eruditos, contribuyendo poderosamente a la configuración de la Res publica literaria, a que se va a referir Erasmo ${ }^{34}$.

No se pretende, sin embargo, ofrecer una visión demasiado reduccionista del

${ }^{34}$ El propio Eneas Silvio Piccolomini( Pío II) no puede menos de rendir homenaje a este aspecto de su predecesor :"Hasta tal punto sacó y alentó talentos Nicolás que resulta difícil dar con otra época en la que los estudios de humanidades, la oratoria y las demás ciencias hayan relucido más que en la suya" (Eneas Silvio Piccolomini, La Europa de mi tiempo, 229). Véase asimismo J. Burckhardt, La cultura del Renacimiento en Italia, Barcelona, Iberia, 1971, 163. 
movimiento humanista, en su oposición al Turco. Tratando de enfocar el problema en su debida amplitud, cabe recordar que el movimiento humanista empieza a configurarse propiamente desde el siglo XIV, que constituye a la vez el periodo en el que se inicia la incursión turca en Europa. Pues bien, ya desde ese siglo XIV emerge en el seno del movimiento humanista la idea de una cruzada contra el Turco, tal como cabe advertir desde Petrarca, en nombre de la defensa de un modelo de civilización, contra una agresión hostil a la tradición europea.

Tal actitud no resulta debidamente comprensible si no tenemos presente que el movimiento humanista va unido a la recuperación por parte de la Cristiandad latina, especialmente por Italia, del estudio del griego y a través de él del acceso directo a las distintas manifestaciones culturales de la Grecia clásica. Todo ello tenía que crear unos vínculos más estrechos con Bizancio, especialmente con Constantinopla, es decir, con aquella parte de Europa que era el objeto primordial de la agresión turca.

Los humanistas, en efecto, empezaron a acudir a Bizancio para adquirir textos del legado griego clásico, y a la vez para alcanzar los conocimientos lingüísticos y filológicos necesarios para su adecuada comprensión. Observemos que ya Petrarca empieza a estudiar el griego y adquiere manuscritos griegos de Homero y Platón y que Boccaccio hace que Leoncio Pilato enseñe griego en Florencia y que traduzca a Homero al latín. Más relevante a este respecto va a ser todavía la llegada a Italia de Manuel Crisolaras y su importante actividad docente en Florencia y en otros lugares de Italia. En este sentido cabría afirmar con Paul Oskar Kristeller que "Con Crisolaras se inicia, más de siglo y medio antes de la caída de Constantinopla, el éxodo hacia Italia de eruditos bizantinos, movimiento que siguió sin interrupción por varias décadas y que aumentará, primero con el Concilio de Florencia y Ferrara en 1438 y, después, con la catástrofe de 1453"35.

En realidad, en todo este periodo, al menos hasta la caída de Constantinopla, nos encontramos con un doble movimiento que fortalece y consolida al movimiento humanista en su acercamiento al legado de la Grecia clásica, con una amplitud y precisión desconocidas anteriormente. Por un lado tenemos la venida a Occidente de sabios y eruditos bizantinos y por otro la ida de tantos humanistas a Constantinopla y a otras ciudades griegas. Ya cuando Crisolaras regresa a Constantinopla lo hace acompañado de varios alumnos italianos. Como resultado de esta interacción tenemos que ya en la primera mitad del siglo XV nos encontramos con humanistas italianos que dominan el griego. Obviamente a través de este contacto con el mundo bizantino se fueron conociendo mucho mejor las grandes aportaciones de la Grecia clásica. Incluso en el campo filosófico se empezaron a conocer muchos textos que pasaron desapercibidos para la Edad Media latina. En algunos casos el desconocimiento era casi total. Y si de la filosofía pasamos a la litera-

35 P.O. Kristeller, El pensamiento renacentista y sus fuentes, México, F.C.E., 1982, 196. 
tura o a la historiografía griegas, el giro que ahora se produce es todavía más radical. Además, estaba el problema de las traducciones. Por meritoria que haya sido la labor llevada a cabo por la Edad Media, no cabe duda de que los humanistas renacentistas van a estar en condiciones mucho más favorables para llevar a cabo un trabajo satisfactorio. Durante mucho tiempo las traducciones al latín - o a algún idioma vernáculo- van a estar a la orden del día, de forma que el acervo bibliográfico puesto a disposición del hombre europeo se va a enriquecer considerablemente. Se vuelven a traducir textos que ya lo habían sido durante la Edad Media y otros muchos lo son ahora por primera vez. También desde este punto de vista Eneas Silvio Piccolomini (Pío II) rinde tributo a su predecesor Nicolás V, al subrayar que mandó buscar libros por toda Grecia y los mandó traducir al latín, siendo sus traductores favoritos "Jorge de Trebisonda, Lorenzo Valla, Pedro Cándido Decembrio y Gregorio di Castello, así como Demetrio, que era griego de nacimiento" 36 .

Tal situación, someramente evocada, nos permite comprender la relevancia que el mundo bizantino, y de una forma señalada su capital Constantinopla, desempeñó en la configuración del humanismo renacentista y, a través de él, en la de la Europa moderna, mediante la apropiación del legado de la Grecia clásica ${ }^{37}$. Y a la vez nos permite comprender la oposición frontal al avance turco sobre Europa como una agresión a un modelo de civilización. De una forma especial resultó traumática para el movimiento humanista la toma de Constantinopla, tan cargada de simbolismo, la caída en manos turcas de aquella ciudad que servía como mediadora, de transmisora del legado de la Grecia clásica, como ninguna otra ciudad era capaz de hacerlo. De ahí que la literatura humanista relativa a la cruzada antiturca prolifere especialmente en los años posteriores a la toma de Constantinopla ${ }^{38}$. En realidad nos encontramos ante un tema favorito de la literatura humanística.

La Europa renacentista se les presentaba como la auténtica heredera del legado grecorromano, como referente de civilización, mientras que los turcos vendrían a ser para ellos los destructores de este modelo, en última instancia como una especie de anti-Europa, tal como diría Marcel Bataillon, al referirse al humanismo renacentista ${ }^{39}$, de nuevo confrontado a la amenaza turca sobre Europa.

Los humanistas enarbolaron la bandera de la cruzada contra el Turco en nombre de la defensa de las bellas letras, de las que los turcos serían enemigos. Sin duda los humanistas no pudieron evitar toda visión estereotipada y simplificada del pro-

\footnotetext{
36 La Europa de mi tiempo, 228.

37 Cabe sin duda suscribir a este respecto las palabras de P. O. Kristeller cuando señala "Si la herencia recibida de la cultura griega antigua, en todos sus aspectos, sigue siendo parte esencial de nuestra civilización, a pesar de los agregados y de las transformaciones traídos por los siglos posteriores, es algo que debemos a los humanistas renacentistas italianos y de otras partes de Occidente, así como a sus predecesores bizantinos" (op. cit., 205).

38 J. Hankins, op. cit., 112.

39 M. Bataillon, “Erasmo, ¿europeo?”, en Revista de Occidente 58(1968), 12-13.
} 
blema, como cabe constatar sin ir más lejos analizando la figura del sultán conquistador de Constantinopla. Pero su denuncia en todo caso estaba lejos de ser arbitraria, pues, por un lado los turcos, cuando toman el liderazgo del Islam en el siglo XIV, están lejos de poseer el desarrollo y esplendor que habían poseído los pueblos del Próximo Oriente - y los árabes de la Península Ibérica - y sus vínculos con el legado clásico se volvían más débiles, mientras que los humanistas europeos redescubrían y se apropiaban ese legado, como inspirador de un modelo de civilización ${ }^{40}$. Y a su vez la experiencia concreta de la dominación turca en los territorios que iban conquistando no era propicia precisamente para poder ver en él la realización de la libertad, la tolerancia y, en general, el cultivo de aquellos valores que acariciaba el humanismo europeo. En concreto los relatos que circulaban profusamente en Occidente acerca de la ocupación turca de Constantinopla, tanto acerca del trato deparado a las personas como al patrimonio religioso y cultural, no propiciaban precisamente el optimismo de los humanistas.

Sobre este contexto emerge la figura de Eneas Silvio Piccolomini como aquel autor que ha tenido en su tiempo una conciencia más clara de Europa. Tal como hemos señalado, a finales de la Edad Media reaparece la conciencia de Europa y nuestro autor se nos presenta como aquél que ha vivido más profundamente esa situación y la ha convertido en objeto privilegiado de su vida y de su obra. Sobre su figura inciden, aparte de una larga y rica tradición, los grandes problemas de aquel peculiar siglo de transición que le correspondió vivir. Vamos a procurar hacernos eco de algunos de sus pronunciamientos, a partir del horizonte que hemos venido esbozando. Nos encontramos ante un Papa humanista que, además, estaba bregado en las lides diplomáticas y políticas, destacando a este respecto la actividad que durante un tiempo desarrolló al servicio del Emperador. En este sentido, L. Pastor le puede describir justamente como "poeta, orador, historiador y hombre de Estado" que se mostraba como "un eminente espíritu crítico, que reunía en sí toda la cultura de su tiempo"41. A ello conviene añadir para nuestro propósito el excelente conocimiento de Europa que él poseía, en buena medida de primera mano. Con todo este bagaje se va a emplear a fondo en defender a Europa frente a la amenaza turca. Con razón se ha podido afirmar que los turcos, y la cruzada contra ellos, constituyeron el tema de la vida y de la muerte de Eneas Silvio Piccolomini (Pío II) ${ }^{42}$. En efecto, el Papa muere cuando se disponía a participar personalmente en una expedición contra los turcos, contra los que va a tratar de esgrimir tanto las fuerzas de la razón como la de las armas. Vamos a intentar hacernos eco de algún aspecto relevante de esta actitud de nuestro autor.

\footnotetext{
40 J. Hankins, op. cit., 145-46.

${ }^{41}$ L. Pastor, Historia de los Papas III, Buenos Aires, G. Gili, 1949, 64-65.

42 B. Guthmüller und W. Kühlman, op. cit., 79.
} 


\section{Eneas Silvio Piccolomini (Pío II) y la caída de Constantinopla}

Como queda apuntado, la caída de la famosa ciudad, aparte de resultar traumática para los territorios directa o indirectamente afectados, también lo va a ser para muchos espíritus de la Cristiandad latina, pertenecientes a los ámbitos eclesiástico y humanístico. La caída tuvo lugar varios años antes de que nuestro autor fuera elegido Papa en 1458. Pero ya muchos años antes de esa elección, Eneas Silvio Piccolomini vivió profundamente el problema de la amenaza turca y de un modo especial se sintió traumatizado por la caída de Constantinopla. Por ello no parece exagerado lo que Nikolaus Giman escribía en 1541 acerca de la reacción de Eneas Silvio ante los acontecimientos de 1453 : "Fuit nemo omnium cui ea tum res magis esset cordi, cuius animum vehementius pungerent Graecorum calamitates, quam huius Pontificis"43. En efecto, este tema aparece casi de una forma obsesiva en la obra del autor, sobre todo en su correspondencia y en sus discursos, a partir del momento mismo en que conoce la traumática noticia. En efecto, recibe la noticia el 12 de julio de 1453 y ese mismo día escribe a Nicolás V una importante carta sobre los graves acontecimientos. Cabría incluso añadir que ya un año antes de la caída de la ciudad aborda el tema de la amenaza turca en el importante discurso Moyses vir Dei pronunciado ante el Papa Nicolás V y el Emperador Federico III, con motivo de la coronación de este último en Roma.

Eneas Silvio Piccolomini es de los autores que no vacila un instante en comparar la toma y el saqueo de Constantinopla con el de Roma por las tropas de Alarico. Tanto la vieja Roma como la nueva habrían sido víctimas del saqueo de los bárbaros. Con una diferencia importante, sin embargo. Las tropas de Alarico habrían respetado al menos las iglesias romanas, bien al contrario de lo que ocurre con los tur$\cos ^{44}$. Reiteradas veces va a insistir, en efecto, en el hecho de la profanación de las iglesias de Constantinopla, empezando por el emblemático templo de Santa Sofía. Especialmente significativa parece la descripción que nos ofrece en el tratado sobre Europa acerca de la irrupción de los turcos en la ciudad : "Durante tres días enteros no hubo nada que se considerara ilegítimo en Constantinopla. La iglesia de Santa Sofía, obra del emperador Justiniano, famosa en todo el mundo y con la que ninguna otra puede compararse, fue despojada de sus sagrados atavíos y abierta a toda clase de inmundicia" 45 . El frente religioso constituye sin duda el aspecto primordial en esta invasión turca, agrediendo una religión que se había ido replegando crecientemente en Europa, una vez que se habían arrebatado a la Cristiandad aquellos territorios de Asia y de África en los que estaba implantada anteriormente.

\footnotetext{
43 Ibid., 80.

44 Opera omnia, 704.

45 La Europa de mi tiempo, 90-91.
} 
Ahora le tocaba el turno a Constantinopla. Ella no era desde luego una parte cualquiera de la Cristiandad sino un miembro especialmente cualificado. Eneas Silvio Piccolomini no duda en considerarla gráficamente como el "segundo ojo" o bien como la "segunda mano" de la Cristiandad46. Y a la vez que subraya la relevancia de Constantinopla, Eneas Silvio Piccolomini también reafirma su europeidad. Frente a la amenaza del enemigo común, Eneas Silvio Piccolomini resalta la europeidad del mundo bizantino, basándose en los aspectos comunes de la cultura europea. Éste es un aspecto sobre el que Eneas Silvio Piccolomini vuelve una y otra vez. Por supuesto lamenta las pérdidas experimentadas por la Cristiandad en tierras de Asia y de África. Precisamente al final de su tratado sobre Asia hace la significativa confesión de que lo ha escrito con el fin de que los que lo lean comprendan "cuánto ha perdido la república cristiana" 47 . Tal circunstancia no puede menos de suscitar una mirada melancólica por parte de Eneas Silvio Piccolomini. Sin embargo, con la toma de Constantinopla se ha producido a sus ojos un salto cualitativo. No sólo cayó en manos del enemigo uno de los "ojos" o bien una de las "manos" de la Cristiandad 48 sino que, además, ello se habría producido en suelo europeo. En su relevante discurso De Constantinopolitana Clade et de bello contra Turcos congregando, después de referirse a la caída de Constantinopla como a una "grandis victoria" de los turcos, como a una "extrema ruina" de los griegos y como a una "summa infamia" de los latinos, hace referencia a que ahora habríamos sido heridos y vulnerados en la patria, en la propia casa, es decir, en Europa :"Retroactis namque temporibus in Asia atque in Africa, hoc est in alienis terris vulnerati fuimus; nunc vero in Europa, id est in patria, in domo propia, in sede nostra percusi caesique sumus"49.

Constantinopla forma parte de la patria, de la propia casa que es Europa. Ningún otro autor medieval había tomado una conciencia tan clara de esa pertinencia, ni tampoco de la europeidad como tal. Frente a la amenaza turca, pasan a un segundo plano las diferencias entre latinos y bizantinos, de las que Eneas Silvio Piccolomini es bien consciente, para dejar paso a la convicción de que, después de todo, unos y otros se remiten al mismo credo religioso y se inspiran en el legado de la Antigüedad clásica. Esta reivindicación de la integridad y de la unidad de Europa no impide, sin embargo, a Eneas Silvio Piccolomini afirmar la superioridad del mundo latino coetáneo, como heredero de la tradición europea. Eneas Silvio no duda en señalar que los griegos decayeron en todos los órdenes de su antigua gran-

\footnotetext{
46 Opera omnia, 679

47 Eneas Silvio Piccolomini (Papa Pío II), Descripción de Asia, Sevilla, Servicio de Publicaciones de la Universidad de Sevilla, 1992, 257.

48 Por supuesto, Eneas Silvio sabe bien que Europa había sido objeto de agresiones en el pasado, pero a sus ojos ninguna sería equiparable a la que ahora ha tenido lugar.

49 Opera omnia, 678.
} 
deza y esplendor ${ }^{50}$. Sea suficiente con remitir aquí a un pasaje del tratado sobre Europa en el que hace referencia a los debates celebrados entre latinos y griegos con motivo del Concilio de Ferrara-Florencia :"los latinos, que ya antaño superaron a los griegos en el arte militar y en glorias guerreras, en nuestra época iban por delante de ellos también en cuestión de letras y conocimientos de toda clase" 51 . Eneas Silvio Piccolomini trataría así de conciliar su reafirmación de la unidad espiritual de Europa, incluida su parte oriental, frente a la amenaza turca, con la convicción de la superioridad de la Cristiandad latina, por mucho que los griegos coetáneos sigan desempeñando un papel fundamental a la hora de transmitir el ingente legado de la Grecia clásica. Ocurre, sin embargo, que esta superioridad, que el Papa humanista no duda en afirmar, se va a ver notablemente alterada y neutralizada por las numerosas tensiones y conflictos políticos que afectaban a Europa Occidental en aquel momento peculiar de su historia.

Pero permaneciendo todavía un instante en la consideración del "lamento" de Eneas Silvio Piccolomini por la caída de Constantinopla, tenemos que hacernos eco del aspecto referente a la relevancia cultural de la ciudad, en buena medida como transmisora del legado de la Grecia clásica. Es un aspecto que no podía faltar en las manifestaciones de un humanista como Eneas Silvio Piccolomini. Sin duda, sus lamentaciones llevan la impronta de la retórica peculiar de un orador consumado como era él, y que exigirían ciertas matizaciones, aun cuando ello no llegara a afectar sin más al fondo de la cuestión. A este respecto, Eneas Silvio Piccolomini expresa de una forma paradigmática el "lamento" por la caída de Constantinopla que tantos humanistas iban a reiterar. Constantinopla era también para él un "monumento de la antigua sabiduría" 52 , a través del que accederíamos al legado literario y filosófico de la antigua Grecia. Y así como los romanos cultos de la Antigüedad peregrinaban a Atenas para aprender el idioma y asimilar el legado cultural de la Grecia clásica, así en la Cristiandad latina medieval, en su periodo final, se producía el desplazamiento a Constantinopla por parte de tantos humanistas, también con vistas al aprendizaje del griego y la toma de contacto con los textos provenientes de la Antigüedad griega. Desde Constantinopla nos habrían llegado los textos de Platón, y asimismo de "Aristóteles, Demóstenes, Jenofonte, Tucídides, Basilio, Dionisio, Orígenes" y de otros muchos. Un proceso que habría de proseguir en el futuro pero que había sido truncado por la invasión turca.

Eneas Silvio Piccolomini se complace en resaltar por doquier, sin preocuparse demasiado de los matices, la hostilidad de los turcos hacia las bellas letras. Así se expresaba, por ejemplo, al mes siguiente de haberse enterado de la caída de

50 De una forma general, sobre esta cuestión véase L. Secchi Tarugo (ed.), Pío II humanista europeo, Firenze, Franco Cesati, 2007, 145-64.

51 La Europa de mi tiempo, 202-03.

52 Opera omnia, 681. 
Constantinopla : "Y ahora los Turcos, enemigos de las letras griegas y latinas, para hacer lugar a sus letras, no permitirán ningún libro ajeno"53. Los intérpretes señalan con razón que sería preciso hacer alguna matización 54 , sin que ello suponga cuestionar sustancialmente las razones que asisten al autor. Se trata sin duda de una especie de leit motiv que encontramos a lo largo de la obra de Eneas Silvio Piccolomini : las conquistas turcas suponen una regresión cultural. Así en su tratado sobre Europa, al referirse a Romania, nación griega, afirma que "tras la destrucción del Imperio griego, ha regresado a la barbarie bajo el dominio turco" 55 . Asimismo en el tratado sobre Asia al referirse a los territorios cristianizados que después pasaron al dominio turco al ser conquistados por ellos, afirma también que en éstos "sucumbieron las letras sagradas y decayó por completo el estudio de las buenas letras" 56 .

Con la caída de Constantinopla, Eneas Silvio Piccolomini ve en serio peligro la pervivencia del legado de la Grecia clásica que, según queda apuntado, tan relevante se iba a mostrar para la configuración de la Europa renacentista. Enfáticamente llega a hablar de la "segunda muerte" de Homero y Platón, como representantes simbólicos de la literatura y la filosofía griegas ${ }^{57}$. Afortunadamente, tales previsiones resultaban demasiado pesimistas en un momento en que el intercambio cultural entre latinos y griegos ya había avanzado mucho y, además, la caída de Constantinopla iba a provocar el conocido éxodo hacia Occidente de sabios cargados de textos pertenecientes al legado griego, por importantes que hayan sido las pérdidas a lamentar.

\section{Una cruzada imposible}

En 1458, cinco años después del acontecimiento traumático de la caída de Constantinopla, Eneas Silvio Piccolomini es elegido Papa con el nombre de Pío II. Muchos son sin duda los problemas con los que tiene que lidiar el nuevo Pontífice, pero, según propia confesión, ninguno será equiparable al de la amenaza turca que se cierne sobre Europa y al de organizar entre los gobernantes y pueblos europeos una cruzada contra el Turco. El propio Papa lo manifiesta así :"Atque inter omnis curas, que animum eius inuasere, nulla maior fuit quam ut in Turcos excitare christianos posset atque his bellum inferre" 58 .

\footnotetext{
53 Ibid., 705.

54 Véase, por ejemplo, R.F. Glei und M. Köhler, Pius II. Papa. Epistola ad Mahumetem, Wissenschaftlicher Verlag, Trier, 2001, 16.

55 La Europa de mi tiempo, 71.

56 Descripción de Asia, 256.

57 Opera omnia, 715.

58 Pío II, Comentarii rerum memorabilium que temporibus suis contingerunt I, Città del Vaticano, Biblioteca Apostólica Vaticana, 1984,113. (En adelante: Comentarii)
} 
La caída de Constantinopla había resultado ciertamente traumática para Eneas Silvio Piccolomini, pero no lo era menos constatar cómo el avance turco sobre Europa no se había detenido precisamente sino que había cobrado nuevos bríos, de forma que una vez producido el desastre de los griegos, cabría esperar el de los latinos si Europa no tomaba las medidas oportunas para su defensa. Sin duda pueblos como los húngaros estaban desempeñando heroicamente el papel de nuevos baluartes de Europa contra el avance del enemigo. De ahí el sentimiento de admiración y de gratitud que Pío II experimenta hacia ellos 59 . Pero los húngaros no podrán, abandonados a sus propias fuerzas, seguir haciendo frente a un enemigo tan poderoso. De ahí la necesidad imperiosa que experimenta el Papa de organizar y liderar la defensa común de Europa. Al viejo motivo de la cruzada religiosa contra el infiel se unía, además, en el ánimo de Pío II, como buen humanista, el imperativo de defender un modelo de civilización contra la barbarie. Cabe en este sentido afirmar que nadie en su tiempo supo personificar tan plenamente el espíritu de cruzada como lo hizo Pío II, aun cuando fracasase en su intento de llevarla a cabo.

Dos serían, a juicio de Pío II, las metas fundamentales de una cruzada europea contra los turcos. En primer lugar recuperar lo perdido a causa de la agresión turca. Estas conquistas turcas se le mostraban como una auténtica usurpación llevada a cabo en la patria común europea. La otra sería evitar los peligros futuros que acechan a Europa, debido a que el avance turco prosigue y Pío II teme vivamente ver al Continente europeo bajo el imperio turco60. Una auténtica pesadilla para el Papa. Éste, por lo demás, se va a mover en una especie de ambivalencia respecto a la capacidad ofensiva del enemigo. Por una parte es bien consciente de su relevancia, de su envergadura, de modo que resultaría indispensable conjuntar las fuerzas de los príncipes cristianos :"nos Turco multo inferiores sumus, nisi christiani reges arma conjungant"61. A la vez Pío II compartía el viejo tópico, proveniente de la Antigüedad clásica, acerca de la superioridad de los europeos sobre los asiáticos. De ahí su convicción de que si los europeos fueran capaces de aunar sus fuerzas, la victoria estaría indiscutiblemente de su parte. Abundando en esto vemos cómo en el propio tratado sobre Europa Pío II expresa su convicción, refiriéndose a la caída de Constantinopla, de que no faltarán, acaso antes de que él muera, quienes "tomen venganza de este ultraje tan grande que se le ha hecho a nuestro Salvador"62.

Se comprende, por tanto, que el nuevo Papa se apresurara a convocar a una reunión a los príncipes europeos, con vistas a organizar la defensa contra los turcos. Esa reunión habría de celebrarse en el año 1459 en la ciudad de Mantua, en una

\footnotetext{
59 Véase, por ejemplo, J. D. Mansi, Sacrorum Conciliorum: nova et amplissima collectio, vol. 32, Graz, Akademische Druck u. Verlaganstalt, 1960, 212. (En adelante: Mansi)

60 Ibid., 209.

61 Comentarii I, 461.

62 La Europa de mi tiempo, 91.
} 
especie de congreso en el que se abordaran en común los problemas comunes de Europa :"in quo de communi salute communiter ageret"63. Sin embargo, su desarrollo se iba a mostrar amargamente decepcionante para el Papa. Ya el propio comienzo de la reunión lo iba a ser : esperaba encontrar a su llegada a Mantua a un buen número de gobernantes o al menos a sus representantes cualificados. No fue así. Apenas había nadie relevante, y ante ello no puede menos de expresar su decepción :"uocabimus príncipes ac populos ut communi consilio rem christianam tueremur : uenimus spe pleni, quam uanam fuisse dolemus" 64 .

Tampoco el posterior desarrollo de los acontecimientos durante el tiempo que iba a durar el congreso va a ser más gratificante para Pío II, pues si con el tiempo fueron llegando varias delegaciones, faltaban los personajes más relevantes y, sobre todo, se puso de manifiesto la falta de voluntad para llegar a compromisos concretos en defensa de Europa. Empezando por la actitud evasiva del propio emperador que, si bien había perdido mucha de su anterior relevancia, seguía siendo una referencia importante a la hora de abordar el problema de la defensa de la Cristiandad. Por su parte, la postura de los príncipes alemanes tampoco iba a mostrase más positiva. Por lo que atañe a Francia, su actitud no va a ser meramente de indiferencia sino más bien de hostilidad, y se va a mostrar mucho más interesada en reafirmar sus pretensiones sobre el reino de Nápoles que en comprometerse en la lucha contra el Turco. Y por lo que se refería a los Estados italianos, había que constatar no sólo las rivalidades existentes entre ellos sino, además, el hecho de la primacía que a sus ojos habían ido adquiriendo los intereses comerciales 65 .

De esta forma, el Papa se ve obligado a constatar su soledad y su impotencia, en la defensa de los intereses comunes de Europa :"Nemo est qui pro communi salute assurgat. Stat mater Ecclesia dolens, et gemens, et non est qui consoletur eam"66. Constatación amarga por parte de Pío II que cae en la cuenta de cómo junto al grave problema de la amenaza turca, aparecía otro, asimismo de gran relevancia, que afectaba a las transformaciones experimentadas en el seno de la sociedad europea y que ya se manifestaban por doquier en aquel siglo de transición que fue el siglo XV. Entre otras consecuencias, ello iba a tener como efecto un declinar del espíritu de cruzada que había caracterizado a épocas anteriores de la Edad Media, y que Pío II no dejaba de seguir evocando, no ocultando su nostalgia por aquellos tiempos en que un Godofredo, un Balduino, un Eustaquio, un Hugo, un Boemundo, un Tancredo y otros esforzados reconquistaron Jerusalén al grito de "Dios lo quiere, Dios lo quiere"67.

\footnotetext{
63 Comentarii I, 114.

64 Mansi, op. cit., 204.

65 L. Pastor, op. cit., 107 ss.

66 Opera omnia, 916.

67 Mansi, op. cit., 220.
} 
Ahora, en cambio, el Papa tiene que constatar las enormes resistencias que presenta Europa para movilizarse contra la agresión perpetrada "en su propia casa", siendo ello manifestación de las importantes transformaciones religiosas y políticas que habían tenido lugar. No es éste el lugar de abordar los cambios que se habían ido produciendo en el seno de la sociedad europea y de los que en parte el propio Pío II es expresión y en parte parecen desbordarle, causándole desconcierto y desorientación. Evoquemos al menos alguna de estas transformaciones. La Europa de su tiempo seguía estando profundamente influida por el Cristianismo, pero a la vez era cierto que la última fase de la Edad Media había incoado un innegable proceso de secularización, en los distintos aspectos de la vida. Hace tiempo que G. Lagarde llamó la atención sobre este hecho ${ }^{68}$. De una forma más puntual cabría referirse a la merma de la autoridad papal en los siglos finales del Medioevo. La defensa anacrónica de la plenitudo potestatis papal, el conflicto con el poder político, de una forma especial con Felipe el Hermoso de Francia y con el emperador Luis de Baviera, el llamado destierro de Aviñón, la pretensión manifiesta de los reyes a "nacionalizar" la Iglesia, sometiéndola a su control en el seno de su territorio y, finalmente, el Cisma de 1378 y la derivación hacia una concepción conciliarista de la autoridad y el gobierno de la Iglesia, tenían que conducir inevitablemente a un quebranto de la autoridad papal y a su capacidad de convocatoria, incluso en una situación de peligro como aquella a que se estaba enfrentando la Europa de Pío II69. Pío II se va a esforzar por recuperar la autoridad y el prestigio papales, pero no deja de ser significativo que incluso él, en sus primeros tiempos, compartiera la concepción conciliarista, a la que después, sin embargo, va a rechazar abiertamente.

Sin duda Pío II se va a emplear a fondo por recuperar en lo posible la autoridad papal en el seno de Europa, continuando con ello la tarea de sus inmediatos predecesores. Pero a la merma inevitable de la autoridad papal, se añadía el hecho de que Europa también había cambiado profundamente desde el punto de vista político, y ello iba a contribuir por su parte a que su ilusión de convertir el Papado en el líder espiritual de Europa en su rechazo de la amenaza turca tropezara con tantas dificultades. Pío II tiene que advertir con pesadumbre que aquella Europa de mediados del siglo XV se presentara, tal como señala Bárbara Baldi, como "una realidad cada vez más fragmentada, dividida en una multiplicidad de Estados soberanos, gobernados por soberanos diversos, separados entre ellos por rivalidades políticas y económicas, y por la prevalencia de los intereses particulares"70.

En efecto, mucho antes de la consolidación de los Estados nacionales con la llegada de los tiempos modernos, ya durante los últimos siglos medievales vemos en

68 G. Lagarde, La naissance de l'esprit lä̈que au déclin du Moyen Age, PUF, París 1942 ss.

69 Véase, por ejemplo, D. Hay, "Sur un problème de terminologie historique : 'Europe' et 'Chrétienté”, en Diogène XVII (1957), 52-53.

70 B. Baldi, "Enea Silvio Piccolomini e il De Europa : umnesimo, religione e política" en Archivio Storico Italiano 161(2003), 640. 
plena gestación todo un proceso político en los distintos regna tendente a una organización autónoma, y que va a desembocar en la formación del Estado moderno. El Imperio va perdiendo poco a poco su antigua relevancia, pues cada vez va a haber más regna que se consideran "exentos" del Imperio, mientras que los juristas al servicio de los reyes inventan la fórmula feliz según la que rex est imperator in regno suo, cabiendo advertir que en la dinámica de la afirmación del Estado están presentes dos procesos complementarios : el de la emancipación de la tutela y control de los poderes universalistas medievales y el de la aspiración al monopolio del poder en el interior del reino, centralizando y absorbiendo poderes que antes se encontraban dispersos ${ }^{71}$.

Eneas Silvio Piccolomini constata con desagrado la fragmentación política de Europa, con la emergencia de las distintas nacionalidades. Frente a esta dinámica predominante en su tiempo, el autor no va a dudar en seguir mostrándose como valedor de las instancias universalistas medievales ${ }^{72}$. El de la Iglesia por supuesto pero también el del Imperio. No en vano Eneas Silvio Piccolomini pasó un tiempo al servicio del emperador, conservando siempre un alto aprecio por Alemania ${ }^{73}$. En consecuencia no puede menos de contemplar con aprehensión la fragmentación política en curso. He aquí un pasaje en el que vemos expresado claramente su punto de vista acerca de esta cuestión :'La Cristiandad no posee una cabeza a la que todos estén dispuestos a obedecer. Ni al Sumo Pontífice ni al Emperador se les da lo que es suyo. No hay ninguna reverencia, ninguna obediencia : como nombres ficticios, como cabezas pintadas, así consideramos al Papa y al Emperador : cada ciudad tiene su propio rey. Hay tantos príncipes como casas. ¿Cómo va a ser posible persuadir a tantas cabezas como rigen el orbe cristiano a que tomen las armas?"74.

Tal va a ser, en efecto, la situación con que se va a encontrar en Mantua y en el periodo posterior cuando trate de unir a una fragmentada Europa política para hacer frente al adversario común. Una Europa renuente a comprometerse en serio en defensa de la "causa común". De este modo el ideal europeísta de Pío II tropezaba con dos escollos : la amenaza constante de los turcos y la desunión política de Europa con toda su secuela de disputas, rencillas, cálculos egoístas, lo que hacía tan difícil la defensa de la mencionada causa común ${ }^{75}$. Y, sin embargo, no se podía

71 M. García Pelayo, Idea de política y otros escritos, Madrid, Centro de Estudios Constitucionales, 1983, 109 ss.

72 Véase C.J. Nederman, "National Sovereignty and Ciceronian Political Thought : Aeneas Silvius Piccolomini and the ideal of universal empire in fifteenth- Century Europe", en History of European Ideas 16(1993), 537 ss.

73 El propio Pío II se expresa de una forma fehaciente a este respecto :"nam Eneas Germanorum semper et laudator et defensor existit, non modo in cardinalatu, uerum etiam in Pontificatu maximo, et Calixtus eum pre ceteris cardinalibus in rebus germanis audiuit" (Comentarii I, 93-94).

74 Opera omnia, 656.

75 La propia caída de Constantinopla es considerada, entre otras cosas, como "Latinorum summa infamia”, debido a la falta de ayuda prestada. 
hacer frente con éxito a la amenaza turca sin la unión y colaboración de los gobernantes cristianos ${ }^{76}$. He aquí una convicción profunda de Pío II que no se cansa de reiterar.

Evidentemente, la renuencia de la Europa política a comprometerse en una guerra contra el Turco no se debía a que esa Europa se hubiera vuelto de repente pacifista. Pío II constataba con pesadumbre los conflictos, disputas y tensiones que desgarraban constantemente a esa Europa, de forma que cabría decir que los cristianos preferían desencadenar guerras civiles entre ellos que hacerlo contra el Turco, y que incluso con frecuencia por asuntos nimios provocaban entre ellos combates cruentisimos :"Pugnare potius inter se Christiani uolunt, quam Turcos adoriri. Ciuilia bella magis cupiunt, quam externa, et saepe paruis de causis cruentissima committunt proelia"77. Se trata de una auténtica pesadilla para Pío II, y de ahí la frecuencia con que aparece el tema a lo largo de su obra, anticipándose a expresar uno de los males crónicos que van a aquejar a Europa a lo largo de su historia, y sobre el que tan a menudo van a volver los humanistas de épocas posteriores.

El sueño de Pío II había consistido en querer agrupar a los gobernantes europeos en torno a una causa común, que consideraba vital para la supervivencia de Europa en el plano religioso, político y cultural, y que dependía a sus ojos de hacer frente con éxito a la amenaza turca. La Europa política, mucho más concentrada en la defensa de sus intereses particulares, apenas le va a secundar, a no ser que estuviera directamente amenazada. Pero a pesar de las amargas decepciones experimentadas, Pío II no va a renunciar a este sueño, hasta el final. Considera que la Cristiandad estaba sumida en una especie de letargo y que no quería despertar del sueño ${ }^{78}$. Un letargo y un sueño que no dejaría de afectar también a amplios sectores eclesiásticos y de la propia opinión pública, renuente a asumir cargas a favor de la cruzada acariciada por el Papa79.

Pío II confiesa haberlo intentado todo para despertar a Europa de ese letargo, de ese sueño, aun cuando no lo haya logrado :"omnes temptate uie sunt; nulla uoto respondit" 80 . Un último intento desesperado para conseguirlo va a consistir en la deci-

\footnotetext{
76 Comentarii I, 460-61.

77 Mansi, op. cit., 211.

78 Ibid.

${ }^{79}$ He aquí un texto perteneciente a los Comentarii en el que Pío II expresa sin ambages toda su decepción por la respuesta dada a su invitación a aliarse contra el Turco :"Nos Turco multo inferiores sumus nisi christiani reges arma conjungant. Querimus hoc efficere, inuestigamus uias; nulla occurrit idonea. Si celebrare conuentum uenit in mentem, docet Mantua uanam esse cogitationem; si legatos mittimus qui regum auxilia petant, deridentur; si decimas imponimus clero, auaritia coargitur; corrodendi auri causa cuncta fieri creduntur. Nemo fidem habet uerbis nostris. Quasi negotiatiores qui respondere creditoribus desierunt sine fide sumus, quecumque agimus in partem deteriorem accipiunt" (Comentarii I, 461).

80 Comentarii II, 770.
} 
sión de Pío II, a pesar de su edad y de su deteriorada salud, de encabezar personalmente la guerra contra el Turco, después de haber constatado el rechazo de los príncipes a implicarse seriamente en la misma. Pensaba que la fuerza de su ejemplo, de su compromiso, empujaría por fin a los príncipes cristianos a salir de su inhibición y a asumir la defensa de la causa común:"hec nisi uia christianos in bellum excitat, nescimus aliam" $"$. Sin embargo, la muerte le iba a sorprender cuando se disponía a embarcarse en esa aventura bélica, y con ello posiblemente le haya liberado a la vez de una nueva decepción.

Quizá Pío II no haya sabido comprender adecuadamente todos los cambios sobrevenidos en la Europa de su tiempo. Pero sí supo percibir certeramente una serie de aspectos que definen la identidad europea. A pesar de la eclosión de particularismos, con toda la serie de secuelas que transforman la faz de Europa, Pío II sigue convencido de la unidad profunda de esa Europa conflictiva. Por ello no duda en referirse a los conflictos entre los europeos, por pronunciados que sean, como "guerras civiles" entre pueblos que comparten las mismas creencias religiosas y tienen las mismas tradiciones culturales. Está convencido por tanto de que a pesar de todos los conflictos una unidad profunda sigue caracterizando a Europa ${ }^{82}$. Una unidad que ya no se daría con los turcos. Por ello cuando en su Epístola a Mehmet II, el sultán conquistador de Constantinopla, aborda la cuestión de los conflictos entre los cristianos distingue claramente esos conflictos de aquellos que surgen entre los cristianos y los turcos. Después de reconocer las disensiones existentes entre los primeros, señala :"Pero no son tan terribles los enfrentamientos entre los cristianos como lo son entre los turcos y los cristianos. El cristiano lucha contra el cristiano por la posesión de las tierras de labor, por un reino, por el poder, por la gloria; contra el turco lo hace por la religión, por la libertad, por la vida"83. Y por supuesto también por un modelo de civilización, pues la mencionada Epistola está llena de referencias a la razón y al constante diálogo existente a lo largo de la historia del Cristianismo entre el legado judeocristiano y el grecorromano. Por ello parece pertinente detenerse un momento en el análisis de dicha misiva, antes de concluir esta aproximación a la idea de Europa de este Papa humanista. Dos son los aspectos que evocaremos brevemente : el sueño del Papa de convertir al sultán al Cristianismo, haciendo de él un segundo Constantino, y la insistencia en la complementariedad de los dos legados que subyacen a la cultura europea, como el fundamento sobre el que asienta su identidad, y que correría serio peligro a causa de la penetración turca en suelo europeo.

\footnotetext{
81 Ibid., 772.

82 Se trata de un tema que, como es sabido, los humanistas posteriores van a seguir reiterando.

83 Eneas Silvio Piccolomini, Epistola a Mehmet II, Consejo Superior de Investigaciones Científicas, Madrid 2003, 63.
} 


\section{A la búsqueda de un nuevo Constantino}

El gran sueño de Pío II había consistido en aglutinar a los gobernantes y pueblos de Europa, que fiel a sus principios, fuera capaz de hacer frente con éxito a la amenaza turca y, de esta forma, poner a salvo a la Cristiandad latina y poder recuperar aquella parte de Europa que tan dolorosamente le había sido amputada. Tal era la meta que se había propuesto convocando a los gobernantes europeos al congreso de Mantua. Sin embargo, su desenlace decepcionante puede explicar que los sueños de Pío II se proyecten por un momento en otra dirección.

Esos nuevos sueños se ven reflejados en la Epistola que escribió al sultán Mehmet II en 1461 y que justamente ha podido ser calificada como una especie de Intermezzo en el espíritu de cruzada que va a caracterizar a Pío II hasta el final ${ }^{84}$. Aunque parece que tal carta nunca fue enviada a su destinatario, no por ello deja de ser relevante para conocer mejor la mente del Papa. Ante el fracaso de los intentos de una defensa armada de Europa, Pío II da rienda suelta a su imaginación y sueña por un momento con la posibilidad de una conversión del sultán al Cristianismo. Con vistas a formular ese sueño escribe la carta, aunque no le sirviera más que para clarificarse a sí mismo.

A diferencia de las posturas más o menor irenistas de Juan de Segovia o de Nicolás de Cusa, Pío II soñó durante un momento con la posibilidad de la conversión del sultán al Cristianismo, presentando a éste como superior al Islam tanto desde el punto de vista religioso como desde su concordancia con la razón. Si esa conversión se produjera, el problema de Europa se solucionaría sin duda en buena medida, al poner a salvo su unidad religiosa y cultural. En el sueño de Pío II, tal eventualidad se le presentaba como el advenimiento de una nueva edad de oro, como la realización de una utopía: "Retornarían los tiempos de Augusto y se renovarían lo que los poetas llaman los siglos de oro" 85 .

Para apuntalar de alguna forma tal posibilidad, Pío II no puede menos de evocar los casos de figuras señeras de la realeza que se convirtieron al Cristianismo y al hacerlo arrastraron también consigo a los pueblos por ellos gobernados: Clodoveo, Esteban, Recaredo... Pero sobre todo sobre la mente del Papa gravitaba el ejemplo ofrecido por el emperador Constantino con su conversión al Cristianismo, constituyendo este hecho un hito decisivo en la historia de Europa. Por ello es el ejemplo principal que Pío II propone a la consideración de Mehmet II, soñando hacer de él una especie de segundo Constantino. Ésta es la invitación :" Pero ¿por qué nos demoramos y no presentamos al mayor ejemplo de todos? El mismísimo Constantino, emperador y monarca, abrió el camino que tú y tus semejantes podéis comenzar sin ninguna duda" 86 .

84 Cfr. B. Guthmüller und W. Kühlmann, op. cit., 124-25.

85 Epistola a Mehmet II, 59.

86 Ibid., 67. 
Si este sueño se llegara a realizar, se produciría una nueva translatio imperii, un tema tan socorrido del pensamiento político medieval. Lo que el sultán ocupaba por la fuerza de las armas, lo podría ocupar con la razón, con el beneplácito de todos. Si el sultán siguiendo el ejemplo de Constantino se convirtiera al Cristianismo, entonces Pío II no dudaría en señalarle :"no habrá en el mundo príncipe que te supere en gloria o pueda igualarte en poder; nosotros te llamaremos emperador de los griegos y de Oriente, y lo que sólo ocupas con violencia y retienes injustamente, lo poseerás con razón" 87 . Este soñado nuevo Constantino devolvería a Europa aquella parte que violentamente le había sido arrebatada y recuperaría su integridad territorial y a la vez la religiosa y cultural. Si esta conversión se llevara a cabo, la Cristiandad estaría incluso en condiciones de recuperar aquellas partes de Asia y de África que le habían sido arrebatadas por el Islam. El Cristianismo serviría así de nuevo como elemento cohesionador de la unidad europea, e incluso más allá de la misma, en este sueño de Pío II. Pero en su esfuerzo por hacer plausible al sultán la aceptación del Cristianismo, Pío II también se va a esforzar por hacerle ver, aparte de los beneficios políticos y religiosos, la convergencia entre el Cristianismo y la razón, entre el legado judeocristiano y el grecorromano, sobre los que, como sabemos, se asienta la identidad europea. Por ello nos detenemos un momento sobre esta cuestión.

\section{Pío II y la defensa de la convergencia de los dos legados que subyacen a la cultura europea}

Pío II va a ser un abanderado de la razón de las armas contra la invasión turca de Europa, pero como buen humanista no podía menos de recurrir asimismo a las armas de la razón. Tal es lo que ocurre de una forma señalada en esa especie de Intermezzo que constituye su Epístola a Mehmet II, el sultán de los turcos. En efecto, la invitación a convertirse al Cristianismo es presentada por Pío II como no arbitraria y absurda sino más bien como algo acorde con la razón. De esta forma, la invitación al sultán a convertirse al Cristianismo implicaba a la vez, tal como señala F. Gaeta, una invitación a convertirse a la "lúcida civilización racional de la Europa culta" 88 .

Quien escribe al sultán es al mismo tiempo Papa y humanista. Ya el propio nombre escogido como Papa revela esa dualidad de hombre religioso y humanista. Al escoger el nombre de "Pío" el humanista Eneas Silvio remitía a un pasaje de la Eneida de Virgilio, uno de sus poetas preferidos. Se trata de aquel pasaje que

87 Ibid., 57.

88 F. Gaeta, "Sulla 'Lettera a Maometto' di Pío II", en Bulletino dell'Istituto Storico Italiano e Archivio Muratoriano 77(1965), 192. 
dice:"Sum pius Aeneas (...)fama super sidera notus"89. Con ello el nuevo Papa quería expresar su doble inserción, en la tradición cristiana y en la de la Antigüedad clásica. Estamos ante el Papa humanista que no dudará en escribir en De Liberorum educatione que nada hay en la tierra más precioso, más apreciable que un entendimiento esclarecido y que sin el cultivo de las letras toda época permanece en la oscuridad $^{90}$. Por otra parte ya hemos visto cómo en el lamento por la caída de Constantinopla está muy presente no sólo el referente religioso sino también el cultural.

Pues bien, tal va a ser asimismo el horizonte desde el que interpela a Mehmet II. Pío II se dirige a él como Papa y como humanista. Por ello la invitación a convertirse al Cristianismo va unida a la invitación a establecer un diálogo basado en la razón. A este respecto, Pío II se complace a lo largo de la Epístola en resaltar la convergencia entre las concepciones mantenidas por el Cristianismo y las de los filósofos griegos ${ }^{91}$. Tal sería el caso, por ejemplo, en el problema de la naturaleza de la Divinidad, de la inmortalidad del alma, del problema del bien supremo, y del de la felicidad..., por mucho que la concepción cristiana vaya más allá del horizonte filosófico. Especialmente significativa parece la forma cómo se refiere al problema de la ley en cuanto expresión de la razón :'Los filósofos dicen que la ley es aquello que se capta por medio de la razón; y hay quienes afirman que la ley no es otra cosa que la recta razón procedente de la voluntad divina. Así pues, todo lo que es contrario a la razón carece del nombre de ley"92. El Papa sugería así al sultán la necesidad de someterse al veredicto de la razón y aspiraba a presentar al Cristianismo no como una filosofía más pero sí como algo acorde con la razón, de forma que la opción por el Cristianismo se presentara como una opción razonable.

En sintonía con ello, Pío II se complace en destacar las grandes figuras que jalonan la historia del pensamiento cristiano, y a los que califica de "excelentísimos maestros de la ley divina y humana"93. Entre ellos Agustín, Jerónimo, Ambrosio, Gregorio, y asimismo los Padres griegos : Basilio, Juan Crisóstomo, Gregorio Nazianceno. O bien los grandes fundadores de Órdenes religiosas : Benito, Basilio el Grande, Bernardo, Bruno, Francisco de Asís, Antonio, Domingo a cuya Orden va a pertenecer figuras señeras como Alberto Magno o Tomás de Aquino.

Arropado por las aportaciones de todos ellos, Pío II se siente orgulloso del pano-

\footnotetext{
89 Virgilio, Eneida 1, 378-79.

90 Opera omnia, 971-72.

91 Con razón se ha podido afirmar que en la Epístola a Mehmet II se puede encontrar "una mezcla de lo sagrado y lo profano en las referencias literarias, en el enfoque de los razonamientos, en las promesas realizadas (gloria terrena y salvación eterna; citas de Platón y Aristóteles junto a los Patriarcas y a los Profetas; el Espíritu Santo y la sabiduría pagana etc.) (Cfr. L. Rotondi Secchi Tarugo (ed.), Pio II e la cultura del suo tempo, 271.

92 Epístola a Mehmet II, 165.

93 Ibid., 183.
} 
rama y el nivel culturales que ofrece la Europa cristiana: "entre nosotros florece completamente el estudio de las artes liberales, se lee públicamente filosofía, se escucha teología en las escuelas, no se pasa por alto ningún tipo de enseñanza"94.

De esta forma, Pío II nos presenta una Europa culturalmente floreciente debido al desarrollo creativo de los dos legados sobre los que en última instancia se apoya, y a las nuevas instancias que se habían ido integrando y desplegando a lo largo del Medioevo. No dudaba de la superioridad cultural de Europa, por más que su visión tendría que ser matizada en varios aspectos. Sin duda no pudo hacer frente a la amenaza turca sobre Europa ni valiéndose de la fuerza de las armas ni de las fuerzas de la razón, y a la vez tampoco fue capaz de hacer que la Europa política, inmersa en la eclosión de las nacionalidades, se elevara a la percepción y defensa del llamado bien común, que implicaba, entre otras cosas, la defensa de su integridad y de su identidad. Pero en todo caso lo que no cabe negar es su especial clarividencia en muchos problemas y que su apasionado compromiso con la causa europea se eleva claramente sobre la cortedad de miras de la Europa política de su tiempo.

Ciertamente, la actitud de Pío II no estuvo exenta de simplificaciones, en más de un sentido, e incluso de anacronismos, que, en parte al menos, son achacables a la situación de acoso en que se encontraba entonces una parte relevante de Europa, e incluso a la idiosincrasia de un carácter "oratorio" y declamador como era la de este Papa humanista, pero al mismo tiempo es preciso reconocer que se trata de un autor que supo percibir con más claridad que nadie en su época el problema de la identidad europea, de sus posibilidades y de sus amenazas, y que se comprometió plenamente con esta cuestión, a pesar de inevitables espejismos. Por ello, al margen de todas las limitaciones que puedan señalarse, parecen tener razón aquellos intérpretes que señalan que este autor merece figurar en el número de los grandes europeístas, un digno precursor de Erasmo y de Vives, en la estela del humanismo cristiano. Lo mismo que a ellos, también a Eneas Silvio Piccolomini le estuvo reservado confrontarse tanto con la grandeza como con la miseria de Europa.

94 Ibid., 169. 